\title{
Streptococcus waius sp. nov., a thermophilic streptococcus from a biofilm
}

\author{
Steve H. Flint, ${ }^{1,2}$ Lawrence J. H. Ward ${ }^{2}$ and John D. Brooks ${ }^{1}$ \\ Author for correspondence: Steve H. Flint. Tel: +64 6350 4649. Fax: +64 63561476 . \\ e-mail: steve.flint@nzdri.org.nz
}

\footnotetext{
1 Institute of Food Nutrition and Human Health, Massey University, Private Bag 11222, Palmerston North, New Zealand

2 New Zealand Dairy Research Institute, Private Bag 11029, Palmerston North, New Zealand
}

\begin{abstract}
Thermophilic streptococci were isolated from biofilms on stainless steel samples exposed to pasteurized skimmed milk and from dairy products from a dairy manufacturing plant. The phenotypic characters of these isolates were distinct from those of other thermophilic streptococci of dairy origin (Streptococcus thermophilus and Streptococcus bovis). Genotypic data [restriction endonuclease analysis, ribotyping, random amplified polymorphic DNA (RAPD) profiles, DNA-DNA hybridization and G+C contents] support the classification of these isolates as a new species. The sequence of the 16S rRNA was compared with that of 29 species of streptococci and shown to be significantly different. The sequence of the 16S-23S rRNA intergenic spacer region also differed from published sequences of closely related species. A fluorescent in situ hybridization probe prepared to a specific part of the $16 \mathrm{~S}$ rRNA gene sequence was able to distinguish the unknown isolates from reference isolates of $S$. thermophilus and $S$. bovis. It is proposed that these thermophilic streptococcal isolates from a dairy environment be classified in the genus Streptococcus as a new species, Streptococcus waius (from waiu, the New Zealand Maori word for milk). The type strain is 3/1' (= NZRCC 20100').
\end{abstract}

Keywords: Streptococcus thermophilus, Streptococcus waius, biofilms, milk

\section{INTRODUCTION}

The genus Streptococcus consists of Gram-positive, spherical or ovoid cells that are typically arranged in chains or pairs. They are facultatively anaerobic, nonsporing, catalase-negative and homofermentative, and have complex nutritional requirements (Hardie \& Wiley, 1994). The thermophilic streptococci are characterized by the ability to tolerate pasteurization $\left(72{ }^{\circ} \mathrm{C}, 15 \mathrm{~s}\right)$ and grow at temperatures up to $52^{\circ} \mathrm{C}$ (Bridge \& Sneath, 1983). Biofilms of thermophilic streptococci on the stainless steel surfaces of dairy manufacturing plants threaten the quality of dairy products (Flint et al., 1997). The release of these bacteria from biofilms has been recorded at $10^{6}$ cells $\mathrm{ml}^{-1}$ (Driessen \& Bouman, 1979). Thermophilic streptococci isolated from dairy environments are often Streptococcus thermophilus or are referred to as ' $S$. thermophilus-like' organisms. The specific iden-

Abbreviations: FISH, fluorescent in situ hybridization; RAPD, random amplified polymorphic DNA.

The GenBank accession numbers for the partial 16S rRNA and complete 165 rRNA sequences and the 16S-23S intergenic spacer region sequence determined in this work are U96621, AF088900 and AF088899, respectively. tification of thermophilic streptococci causing problems in the manufacture of dairy products would assist in identifying the source of the contamination and in developing methods to control contamination in dairy manufacture.

The taxonomic status of $S$. thermophilus has varied because of the close relationship between these streptococci and Streptococcus salivarius. S. thermophilus became $S$. salivarius subsp. thermophilus (Farrow \& Collins, 1984) until separate species status was reproposed by Schleifer et al. (1991) on the basis of genetic and phenetic criteria. 16S rRNA sequence data have demonstrated that $S$. thermophilus is closely related to $S$. salivarius and Streptococcus vestibularis.

Streptococcus bovis is another thermophilic streptococcus found in milk. Classification of this organism was hindered by the biochemical heterogeneity of the strains. Genetic studies confirmed that $S$. bovis was indeed made up of several distinct 'species' (Coykendell \& Gustafson, 1985; Farrow et al., 1984), although full descriptions of these have not been published. 16S rRNA sequence data representing only one of the three homology groups of S. bovis described by Wood \& Holzapfel (1995) are currently available 
from the GenBank database. In addition, information from DNA-DNA hybridization has demonstrated a close relationship between $S$. bovis and Streptococcus equinus (Wood \& Holzapfel, 1995).

In this study, we examined isolates of thermophilic streptococci from dairy products or biofilms resulting from the exposure of stainless steel to pasteurized skimmed milk. These organisms were classified using phenotypic observations (including biochemical profiles), restriction endonuclease analysis, ribotyping, random amplified polymorphic DNA (RAPD) analysis, DNA-DNA hybridization, $\mathrm{G}+\mathrm{C}$ contents and comparison of the nucleic acid sequences of the $16 \mathrm{~S}$ rRNA gene and the $16 \mathrm{~S}-23 \mathrm{~S}$ intergenic spacer region. Specific sequences were used to develop a fluorescent probe to identify these bacteria in situ using epifluorescence microscopy.

\section{METHODS}

Organisms. Thermophilic streptococci were isolated from biofilms formed on stainless steel exposed to pasteurized skimmed milk in the laboratory (strains $7 \mathrm{c}, 3 / 1$ and 6/2) and from casein (strain T). S. thermophilus strains H, L3 and BCD7 were isolated from dairy manufacturing plants. These strains were compared with the reference $S$. thermophilus strain ATCC 19258 (type strain) and the reference $S$. bovis strain ATCC 33317. All thermophilic streptococci were cultured in M17 broth or on M17 agar (Difco) at $37^{\circ} \mathrm{C}$ for $18 \mathrm{~h}$.

Phenotypic characters. The four unknown isolates of thermophilic streptococci (T, 7c, 3/1 and 6/2) were compared with reference strains of $S$. thermophilus and $S$. bovis. Colony morphology on M17 agar and the Gram stain reaction of each isolate were observed. All isolates were tested for the ability to grow in and clot $10 \%(\mathrm{w} / \mathrm{v})$ reconstituted skimmed milk at $45^{\circ} \mathrm{C}$. Growth was monitored in reconstituted skimmed milk from 20 to $60^{\circ} \mathrm{C}$ using a gradient temperature incubator (Toyo Kagatu Sangyo) and using $\mathrm{pH}$ reduction to indicate growth.

Growth was monitored in $\mathrm{M} 17$ broth over a range of $\mathrm{pH}$ $(4 \cdot 0-10 \cdot 0)$, in the presence of $\mathrm{NaCl}(1-7 \%, \mathrm{w} / \mathrm{v})$ and bile $(1-2 \%, w / v)$.

The API (LaBalme Les Grottes) ID 32S system was used in an attempt to identify the isolates according to their biochemical profiles. The API $50 \mathrm{CH}$ system was used to provide more comprehensive information on carbohydrate metabolism.

The API ZYM system was used to compare the activity of 19 enzymes from cultures of each isolate.

Restriction endonuclease analysis. Genomic DNA was extracted using a procedure based on that of Marmur (1961). DNA samples $(2 \mu \mathrm{g})$ were digested with EcoRI (Boehringer Mannheim) according to the manufacturer's instructions. The digested DNA was separated on a $1 \%(\mathrm{w} / \mathrm{v})$ agarose gel.

Ribotyping. Digested DNA was transferred from agarose gels to Hybond- $\mathrm{N}^{+}$membrane (Amersham) by the method of Southern (1975). The enhanced chemiluminescent method (ECL; Amersham) was used for DNA hybridization and detection according to the manufacturer's instructions. The rRNA gene probe was the PCR product amplified from the $16 \mathrm{~S}$ rRNA gene as described below.
RAPD comparison. Randomly primed profiles of the strains were generated using the primer RP ( $5^{\prime}$-CAGCACCCAC$\left.3^{\prime}\right)$ under the following conditions: 1 cycle of $94^{\circ} \mathrm{C}$ for $3 \mathrm{~min}, 45^{\circ} \mathrm{C}$ for $45 \mathrm{~s}$ and $72{ }^{\circ} \mathrm{C}$ for $1 \mathrm{~min} ; 30$ cycles of $94^{\circ} \mathrm{C}$ for $45 \mathrm{~s}, 45^{\circ} \mathrm{C}$ for $45 \mathrm{~s}$ and $72^{\circ} \mathrm{C}$ for $1 \mathrm{~min} ; 1$ cycle of $94{ }^{\circ} \mathrm{C}$ for $45 \mathrm{~s}, 45^{\circ} \mathrm{C}$ for $45 \mathrm{~s}$ and $72^{\circ} \mathrm{C}$ for $5 \mathrm{~min}$. Amplification products were separated on a $2 \%(\mathrm{w} / \mathrm{v})$ agarose gel.

DNA-DNA hybridization. DNA $\left(1 \mu \mathrm{g} \mathrm{ml}^{-1}, 100 \mu \mathrm{l}\right)$ from $S$. thermophilus, Streptococcus waius and $S$. bovis was diluted in twofold serial dilutions in $10 \times \mathrm{SSC}(1.5 \mathrm{M} \mathrm{NaCl}, 0.15 \mathrm{M}$ trisodium citrate) to provide concentrations of $0 \cdot 125-1 \mu \mathrm{g}$ DNA $200 \mu \mathrm{l}^{-1}$. Six replicate $200 \mu \mathrm{l}$ samples of each dilution were loaded onto Nylon blotting membrane (Hybond-N + ; Amersham) using a dot-blot filtration manifold system. The membrane was removed from the blotting apparatus, cut into six blocks of replicate samples and placed in denaturing solution $(1.0 \mathrm{M} \mathrm{NaOH}, 3.0 \mathrm{M} \mathrm{NaCl})$, followed by neutralizing solution $(0.5 \mathrm{M}$ Tris $/ \mathrm{HCl} \mathrm{pH} 7.5,1.5 \mathrm{M} \mathrm{NaCl})$ for $5 \mathrm{~min}$, each at room temperature. The membrane pieces were placed between two sheets of blotting paper, air-dried and then baked in a vacuum oven at $80^{\circ} \mathrm{C}$ for $2 \mathrm{~h}$. The membranes were placed in glass hybridization tubes with $10 \mathrm{ml}$ Rapid-hyb buffer (Amersham) pre-warmed to $65^{\circ} \mathrm{C}$ and incubated for $1 \mathrm{~h}$ at $65^{\circ} \mathrm{C}$. Probes were prepared to the three strains ( $S$. thermophilus, $S$. waius and $S$. bovis) by labelling with ${ }^{32} \mathrm{P}$ using the Rediprime DNA labelling system (Amersham). Two replicate membranes were incubated with one of the three ${ }^{32} \mathrm{P}$-labelled probes at $65^{\circ} \mathrm{C}$ for $12 \mathrm{~h}$. The hybridization solution was removed and the membranes washed twice with $2 \times \mathrm{SSC}$ at room temperature for $15 \mathrm{~min}$. The membranes were washed either under conditions of high stringency $(0.1 \times \mathrm{SSC}$ at room temperature for $15 \mathrm{~min}$ followed by $0.1 \times \mathrm{SSC}$ at $45^{\circ} \mathrm{C}$ for $15 \mathrm{~min}$ ) or at lower stringency (two washes with $0.5 \times \mathrm{SSC}$ at room temperature for $15 \mathrm{~min}$ ). The amount of ${ }^{32} \mathrm{P}$ bound to each DNA sample was determined using a Packard scintillation counter.

$\mathbf{G}+\mathbf{C}$ contents. The melting temperature $\left(T_{m}\right)$ of the DNA $\left(20 \mu \mathrm{g} \mathrm{ml}^{-1}\right)$ was determined by monitoring the increase in optical density at $260 \mathrm{~nm}$ with increasing temperatures at $1{ }^{\circ} \mathrm{C}$ increments from $80^{\circ} \mathrm{C}$ using a Gilford spectrophotometer model 260. The base composition of DNA was determined from its melting temperature (Marmur \& Doty, 1962).

PCR amplification using 23S rRNA primers specific for $S$. thermophilus. A specific primer for $S$. thermophilus, $23 \mathrm{~S}$ therm (5'-CATGCCTTCGCTTACGCT-3'), together with a universal primer, 23L (5'-CGCAAACCGACAACAGGTAG-3'), were used in a PCR to determine if the isolates were $S$. thermophilus by the production of a PCR product from the 23S rRNA gene (Schleifer et al., 1995). PCR conditions used here and in the following assays were 1 cycle of $95^{\circ} \mathrm{C}$ for $3 \mathrm{~min}, 55^{\circ} \mathrm{C}$ for $45 \mathrm{~s}$ and $72^{\circ} \mathrm{C}$ for $1 \mathrm{~min} ; 40$ cycles of $95^{\circ} \mathrm{C}$ for $45 \mathrm{~s}, 55^{\circ} \mathrm{C}$ for $45 \mathrm{~s}$ and $72^{\circ} \mathrm{C}$ for $1 \mathrm{~min}$; 1 cycle of $95^{\circ} \mathrm{C}$ for $45 \mathrm{~s}, 55^{\circ} \mathrm{C}$ for $45 \mathrm{~s}$ and $72^{\circ} \mathrm{C}$ for $5 \mathrm{~min}$. PCR amplification using 16S rRNA primer specific for $S$. bovis. The specific primer Bovis (5'-CATCTAACATGTGTTAAATGC-3') was used in conjunction with the universal primer Y1 (5'-TGGCTCAGAACGAACGCTGGCCCG-3') (Young et al., 1991) to amplify a product of approximately $190 \mathrm{bp}$ from the 16S rRNA gene of $S$. bovis strains.

PCR amplification and sequencing of 16S rRNA. A series of fragments representing 1484 bp of 16S rRNA was amplified using a selection of PCR primers. The 16S rRNA fragments were purified for sequence analysis using the Wizard (Promega) system. The fragments were sequenced by the 
Table 1. Biochemical test profile of S. waius, S. thermophilus and S. bovis

Data shown are positive results from 49 tests using the API $50 \mathrm{CH}$ test kit, two replicates for each strain.

\begin{tabular}{|lcccccc|}
\hline Test & $\begin{array}{c}\text { S. waius } \\
\text { 3/1 }\end{array}$ & $\begin{array}{c}\text { S. waius } \\
\text { 6/2 }\end{array}$ & $\begin{array}{c}\text { S. waius } \\
\text { Sc }\end{array}$ & $\begin{array}{c}\text { S. waius } \\
\text { S. thermophilus }\end{array}$ & $\begin{array}{c}\text { S. bovis } \\
\text { ATCC 19258 }\end{array}$ \\
ATCC 33317 \\
\hline Glycerol & + & - & - & - & - & - \\
D-Arabinose & - & - & - & - & - & + \\
Galactose & + & + & + & + & - & + \\
D-Glucose & + & + & + & + & + & + \\
D-Fructose & + & + & + & + & + & + \\
D-Mannose & + & + & + & + & + & + \\
$N$-Acetylglucosamine & + & + & + & + & + & + \\
Amygdalin & - & - & - & - & - & + \\
Arbutine & - & - & - & - & - & + \\
Aesculin & - & - & - & - & - & + \\
Salicin & + & + & + & + & - & + \\
Cellobiose & + & + & + & + & - & + \\
Maltose & + & + & + & + & - & + \\
Lactose & + & + & + & + & + & + \\
Melibiose & + & + & + & + & - & + \\
Saccharose & + & + & + & + & + & + \\
Inulin & - & - & - & - & - & + \\
D-Raffinose & + & + & + & + & - & + \\
Amidon & - & - & - & - & - & + \\
Glycogen & - & - & - & - & - & + \\
$\beta$-Gentiobiose & - & - & - & - & - & + \\
\hline
\end{tabular}

Table 2. Enzyme profiles of S. waius, S. thermophilus and S. bovis

Data shown are positive reactions from the API ZYM assay, two replicates for each strain.

\begin{tabular}{|c|c|c|c|c|c|c|}
\hline Enzyme & $\begin{array}{l}\text { S. waius } \\
3 / 1^{\mathrm{T}}\end{array}$ & $\begin{array}{l}\text { S. waius } \\
6 / 2\end{array}$ & $\begin{array}{l}\text { S. waius } \\
7 \mathrm{c}\end{array}$ & $\begin{array}{l}\text { S. waius } \\
\mathrm{T}\end{array}$ & $\begin{array}{l}\text { S. thermophilus } \\
\text { ATCC } 19258^{\mathrm{T}}\end{array}$ & $\begin{array}{c}\text { S. bovis } \\
\text { ATCC } 33317\end{array}$ \\
\hline Esterase $\mathrm{C} 4$ & - & - & - & - & - & + \\
\hline Esterase lipase $\mathrm{C} 8$ & - & - & - & - & - & + \\
\hline Leucine arylamidase & + & + & + & + & + & + \\
\hline Valine arylamidas̀ & + & + & + & + & + & + \\
\hline Cystine arylamidase & + & + & + & + & + & + \\
\hline Trypsin & - & - & - & - & - & + \\
\hline Acid phosphatase & + & + & + & + & + & + \\
\hline$\alpha$-Galactosidase & + & - & + & + & + & + \\
\hline$\beta$-Galactosidase & + & + & + & + & + & - \\
\hline$\alpha$-Glucosidase & + & - & + & - & - & + \\
\hline$\beta$-Glucosidase & - & - & - & - & - & + \\
\hline
\end{tabular}

Massey University DNA Analysis Service.The sequences were compared with those in the Ribosomal Database Project (Maidak et al., 1997) in an attempt to classify the unknown thermophilic streptococci. Sequences were aligned using the CLUSTAL-x program (Thompson et al., 1997) and sequence homology was calculated with GeneDoc (Nicholas $\&$ Nicholas, 1997). Genetic distances were obtained from the alignments using the DNADIST program of the PHYLIP package (Felsenstein, 1989) which also enabled the con- struction of a dendrogram with the neighbour-joining tree prepared using the Kimura two-parameter correction.

PCR amplification and sequencing of the 165-23S rRNA intergenic sequence. The spacer region between the $16 \mathrm{~S}$ and 23S rRNA was amplified using PCR primers 16S EXT (5'GGGTGAAGTCGTAACAAGGTAGCC-3') and 23S EXT (5'-GCTCCTAGTGCCAAGGCATCCACC-3'). The sequence of this region was compared with the intergenic spacer region of closely related streptococci. 
Preparation and use of a fluorescent probe for in situ hybridization. The specific sequence selected for the preparation of a fluorescent probe to the unknown isolates was a $22-$ mer containing $12 \mathrm{bp}$ from the $\mathrm{V} 2$ region encoding $16 \mathrm{~S}$ rRNA which were different from those of $S$. thermophilus and $S$. bovis (5'-GTCTCTAACATGTGTTAAACAC-3') (Fig. 3). The specificity of this sequence was confirmed using this primer in conjunction with primer $\mathrm{Y} 1$ in PCR to amplify the nucleic acid containing these sequences from the 16S rRNA gene of the unknown isolates and known isolates of $S$. thermophilus and $S$. bovis. Fluorescent probes were synthesized by Oligos Etc. with either a rhodamine label or a fluorescein label at the $5^{\prime}$-end.

The protocol of Poulsen (1995) was used for fluorescent in situ hybridization (FISH). Stainless steel samples with cells of thermophilic streptococci attached were fixed in $4 \%(\mathrm{v} / \mathrm{v})$ formaldehyde at $4{ }^{\circ} \mathrm{C}$ overnight and dehydrated in an ethanol series [50, 80 and $96 \%(\mathrm{v} / \mathrm{v})$ ethanol, $3 \mathrm{~min}$ each]. A hybridization mix containing $40 \%(\mathrm{v} / \mathrm{v})$ formamide and $2.5 \mathrm{ng}$ probe $\mu \mathrm{l}^{-1}$ was added to the surface of the sample and incubated at $37^{\circ} \mathrm{C}$ for $18 \mathrm{~h}$. Following hybridization, the samples were washed three times with hybridization solution without the probe, and then with a washing solution (1 M Tris $\mathrm{pH} 7 \cdot 2,5 \mathrm{M} \mathrm{NaCl}$ ). Samples were observed under epifluorescence microscopy using a Leitz Ortholux II microscope with an $\mathrm{I}_{2}$ incident light filter, producing an excitation wavelength of $450-490 \mathrm{~nm}$.

Replicate samples of stainless steel with the bacteria attached to the surface were stained with $0.001 \%$ acridine orange for $2 \mathrm{~min}$ and the total number of bacteria per $\mathrm{cm}^{2}$ were counted using epifluorescence microscopy at $450-490 \mathrm{~nm}$.

(a)

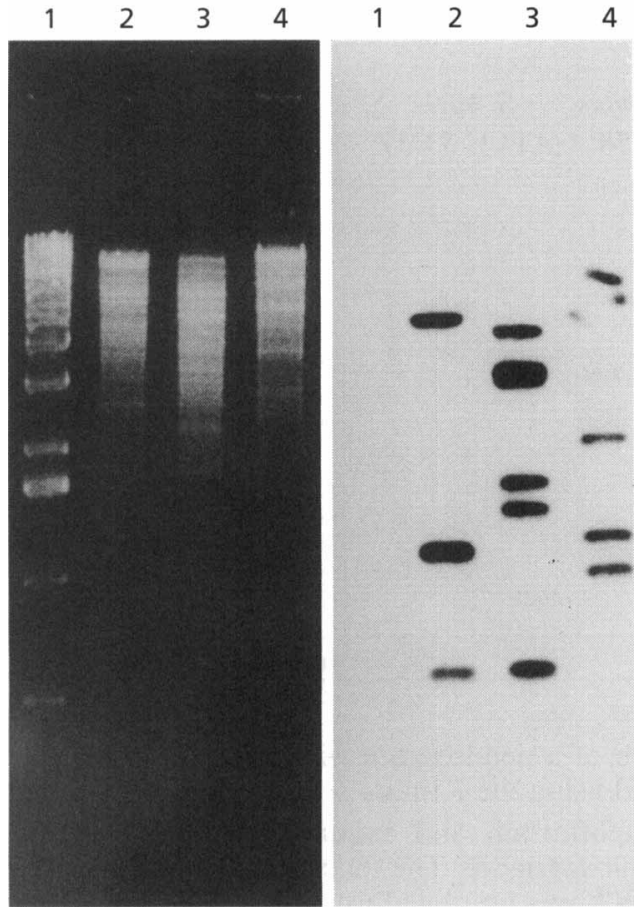

Fig. 1. EcoRI digestion of total DNA (a) and ribotype profiles (b). Lanes: 1, BRL $1 \mathrm{~kb}$ ladder; 2 , S. waius $3 / 1^{\mathrm{T}} ; 3$, S. bovis ATCC $33317 ; 4$, S. thermophilus ATCC $19258^{\top}$.

\section{RESULTS}

\section{Phenotypic characters}

Colonies of thermophilic streptococcal unknown isolates $\mathrm{T}, 7 \mathrm{c}, 3 / 1$ and $6 / 2$ on M17 agar appeared as pinpoint colonies that were indistinguishable from the colonies of the reference strain of $S$. thermophilus. In Gram stains, the cells all appeared as small $(0.7 \mu \mathrm{m}$

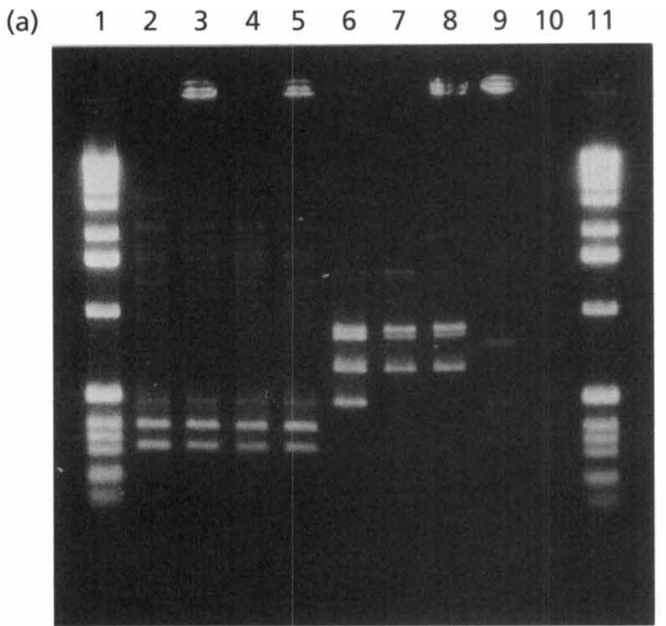

(b)

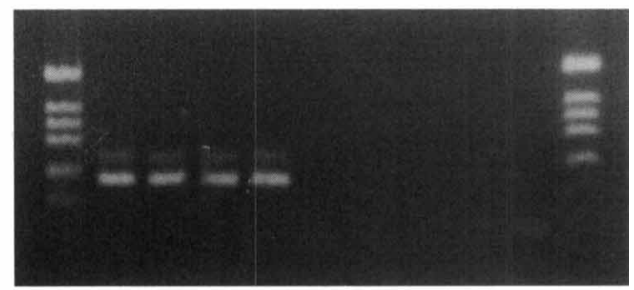

(c)

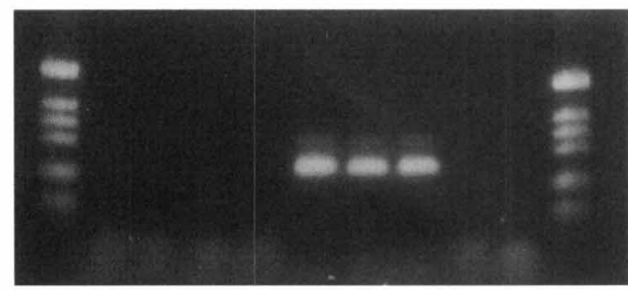

(d)

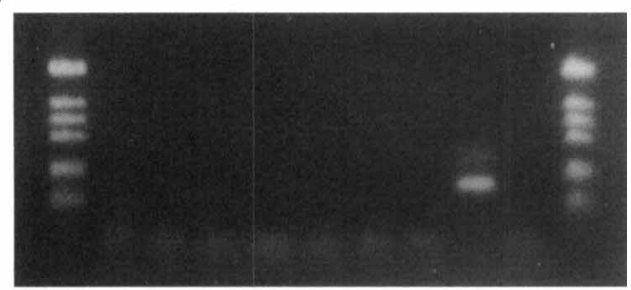

Fig. 2. RAPD profiles (a), and $P C R$ products obtained from amplification of total bacterial DNA with primer combinations specific for S. waius (b), S. thermophilus (c) and S. bovis (d). Lanes: 1 and 11, BRL $1 \mathrm{~kb}$ ladder; $2, S$. waius $3 / 1^{\top} ; 3, S$. waius $6 / 2 ; 4, S$. waius $7 \mathrm{C} ; 5$, S. waius $\mathrm{T} ; 6, \mathrm{~S}$. thermophilus ATCC $19258^{\top} ; 7$, S. thermophilus $\mathrm{H} ; 8$, S. thermophilus L3; 9, S. bovis ATCC $33317 ; 10$, negative control. 
Table 3. DNA-DNA hybridization (\% homology) of S. waius $3 / 1^{\top}$, S. thermophilus ATCC $19258^{\top}$ and S. bovis ATCC 33317 at high and low stringency

\begin{tabular}{|lccccccc|}
\hline Probe & \multicolumn{3}{c}{ High stringency } & & \multicolumn{3}{c|}{ Low stringency } \\
\cline { 2 - 4 } \cline { 7 - 8 } & S. waius & S. thermophilus & S. bovis & & S. waius & S. thermophilus & S. bovis \\
\hline S. waius & 100 & $9 \cdot 6$ & $22 \cdot 3$ & & 100 & $10 \cdot 3$ & $32 \cdot 3$ \\
S. thermophilus & $7 \cdot 5$ & 100 & $9 \cdot 1$ & & $10 \cdot 3$ & 100 & $9 \cdot 9$ \\
S. bovis & $23 \cdot 7$ & $9 \cdot 5$ & 100 & & $25 \cdot 2$ & $10 \cdot 2$ & 100 \\
\hline
\end{tabular}

Table 4. $\mathrm{G}+\mathrm{C}$ contents for $S$. thermophilus ATCC $19258^{\top}$ and $S$. waius $3 / 1^{\top}$ determined from the DNA melting temperature

\begin{tabular}{|lcccc|}
\hline DNA source & $\begin{array}{c}\boldsymbol{T}_{\mathrm{m}} \text { measured } \\
\left({ }^{\circ} \mathbf{C}\right)^{*}\end{array}$ & $\begin{array}{c}\boldsymbol{T}_{\mathrm{m}} \text { published } \\
\left({ }^{\circ} \mathbf{C}\right) \dagger\end{array}$ & $\begin{array}{c}\mathbf{G}+\mathbf{C} \text { measured } \\
(\mathbf{m o l} \%) \ddagger\end{array}$ & $\begin{array}{c}\mathbf{G}+\mathbf{C} \text { published } \\
(\mathbf{m o l} \%) \dagger\end{array}$ \\
\hline S. thermophilus & 86.5 & 85.7 & 41.9 & 40.0 \\
S. waius & 83.5 & - & 34.6 & - \\
\hline
\end{tabular}

* Standard deviation $=0.53$.

$\dagger$ Data from Hardie (1986).

$\ddagger$ Standard deviation $=1.4$.

diameter) spherical cells in pairs, typical of $S$. thermophilus. All isolates were able to clot milk following $18 \mathrm{~h}$ incubation at $45^{\circ} \mathrm{C}$. The range and optimum growth temperatures for the unknown isolates were 24.5 $52.4^{\circ} \mathrm{C}$ and $38.8^{\circ} \mathrm{C}$, respectively. The range and optimum growth temperatures for $S$. thermophilus were $28.8-55.3$ and $40.9{ }^{\circ} \mathrm{C}$, respectively. The range and optimum growth temperatures for $S$. bovis were $27.0-45.9^{\circ} \mathrm{C}$ and $35.9^{\circ} \mathrm{C}$, respectively.

Growth of the unknown isolates was detected over the $\mathrm{pH}$ range $4 \cdot 0-10 \cdot 0$ and at salt concentrations up to $7 \%$. The isolates were intolerant of bile at $1 \%$.

The unknown isolates could not be identified using the API ID $32 S$ test kit.

The reference strain of $S$, thermophilus produced a positive reaction in 6/49 tests of the API $50 \mathrm{CH}$ test kit, compared with $20 / 49$ tests for $S$. bovis. The unknown isolates (T, 7c and 6/2) produced 12/49 positive results and isolate $3 / 1$ produced $13 / 49$ positive results (Table 1).

The unknown isolates produced 5-7 reactions using the API ZYM test kit. $S$. thermophilus produced a similar set of reactions to the unknown isolates. $S$. bovis produced 10 reactions (Table 2).

\section{Restriction endonuclease analysis, ribotyping and RAPD profiles}

Digestion of total DNA and ribotyping produced profiles of digested fragments for the unknown isolates that were different from $S$. thermophilus and $S$. bovis (Fig. 1). RAPD analysis also differentiated these organisms (Fig. 2).

\section{DNA-DNA hybridization}

DNA-DNA hybridization also differentiated the three organisms and confirmed the results from the biochemical data indicating a closer relationship between the unknown isolates and $S$. bovis than between the unknown isolates and $S$. thermophilus (Table 3 ).

\section{$\mathbf{G}+\mathbf{C}$ ratio}

The $\mathrm{G}+\mathrm{C}$ ratio for $S$. waius was $34.6 \mathrm{~mol} \%$ (Table 4 ).

PCR amplification using 235 rRNA primers specific for $S$. thermophilus and 16S rRNA primers specific for $S$. bovis

No PCR product was produced from the four unknown isolates using the 23S rRNA primer combination specific for $S$. thermophilus or the 16S rRNA primer combination specific for $S$. bovis (Fig. 2). A PCR product was produced from all three of the $S$. thermophilus isolates tested with the primer combination for $S$. thermophilus (Fig. 2). A PCR product was also produced from the reference isolate of $S$. bovis using the primer combination specific for S. bovis (Fig. 2). 
Table 5. Percentage homology of the 165 rRNA of $S$. waius compared with 29 other streptococci

\begin{tabular}{|lcc|lcc|}
\hline Species & $\begin{array}{c}\text { Accession } \\
\text { no. }\end{array}$ & $\begin{array}{c}\text { Homology } \\
\text { (\%) }\end{array}$ & \multicolumn{1}{|c|}{ Species } & $\begin{array}{c}\text { Accession } \\
\text { no. }\end{array}$ & $\begin{array}{c}\text { Homology } \\
\text { (\%) }\end{array}$ \\
\hline S. bovis & $\mathrm{X} 58317$ & 94 & S. acidominimus & $\mathrm{X} 58301$ & 82 \\
S. uberis & $\mathrm{U} 41048$ & 93 & S. cecorum & $\mathrm{X} 54290$ & 82 \\
S. thermophilus & $\mathrm{X} 68418$ & 92 & S. pyogenes & $\mathrm{M} 58835$ & 82 \\
S. salivarius & $\mathrm{M} 58839$ & 91 & S. dysgalactiae & $\mathrm{X} 59030$ & 82 \\
'S. milleri' & $\mathrm{X} 81023$ & 89 & S. criceti & $\mathrm{X} 58305$ & 82 \\
S. parasanguinis & $\mathrm{X} 53652$ & 88 & S. oralis & $\mathrm{X} 58308$ & 82 \\
S. mitis & $\mathrm{D} 38482$ & 87 & S. pneumoniae & $\mathrm{X} 58312$ & 81 \\
S. gordonii & $\mathrm{D} 38483$ & 86 & S. equi & $\mathrm{X} 58314$ & 81 \\
S. equinus & $\mathrm{X} 58318$ & 85 & 'S. criae & $\mathrm{X} 58316$ & 81 \\
S. ratti & $\mathrm{X} 58314$ & 84 & S. suis & $\mathrm{X} 59031$ & 81 \\
S. sobrinus & $\mathrm{X} 58307$ & 83 & S. macacae & $\mathrm{X} 58302$ & 80 \\
S. vestibularis & $\mathrm{X} 58321$ & 83 & S. porcinus & $\mathrm{X} 58317$ & 80 \\
S. mutans & $\mathrm{X} 58303$ & 83 & S. anginosus & $\mathrm{X} 58310$ & 80 \\
S. agalactiae & $\mathrm{X} 59032$ & 83 & S. pleomorphus & $\mathrm{M} 23730$ & 78 \\
S. canis & $\mathrm{X} 59061$ & 83 & & & \\
\hline
\end{tabular}

\section{5 rRNA and 16S-23S rRNA intergenic spacer region comparisons with published sequences}

A comparison of 16S rRNA from the unknown isolates with published sequences of 29 different streptococci showed the unknown isolates to be most closely related to $S$. bovis (Table 5, Fig. 3).

The 16S-23S rRNA intergenic spacer region differed from the most closely related streptococci for which sequence data are available $[S$. bovis (GenBank accession no. U39766, 93.0\% homology); S. thermophilus (U32965, 89.5\% homology); and S. salivarius (X83760, 87.7\% homology)] (Fig. 4).

The differences in homology of the 16S rRNA and the 16S-23S rRNA intergenic spacer region together with the biochemical and other molecular data, support the classification of the unknown isolates in a new species. We propose a new species with the name Streptococcus waius, after the New Zealand Maori word for milk, reflecting the origin of these isolates.

\section{Species-specific oligonucleotide and FISH detection}

An identical PCR product (Fig. 2) was produced from all four unknown isolates using a 22-mer primer from the variable V2 region of the genome encoding $16 \mathrm{~S}$ rRNA (Fig. 3) in conjunction with the conserved primer Y1. No product was obtained when this primer combination was used with the $S$. thermophilus or $S$. bovis strains.

The fluorescein-labelled oligonucleotide specific for $S$. waius was able to be used to identify these unknown isolates attached to stainless steel in a FISH reaction. The $S$. waius oligonucleotide did not react with $S$.

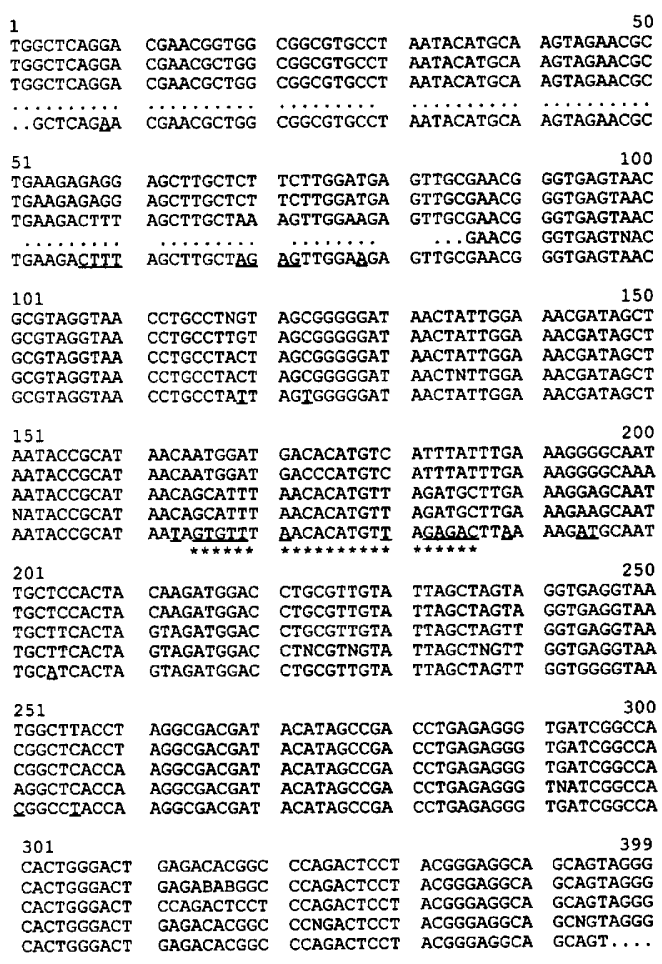

Fig. 3. Alignment of part of the 165 rRNA gene sequences from S. thermophilus (GenBank X68418), S. salivarius (GenBank M58839), S. bovis (GenBank X58317), S. equinus (GenBank $\mathrm{X58318}$ ) and $S$. waius sp. nov. The bases of $S$. waius that are underlined differ from one or more of the other species listed. Asterisks denote the 22-mer primer specific for $S$. waius.

thermophilus or $S$. bovis and therefore was able to differentiate $S$. waius from other thermophilic streptococci (Table 6). 


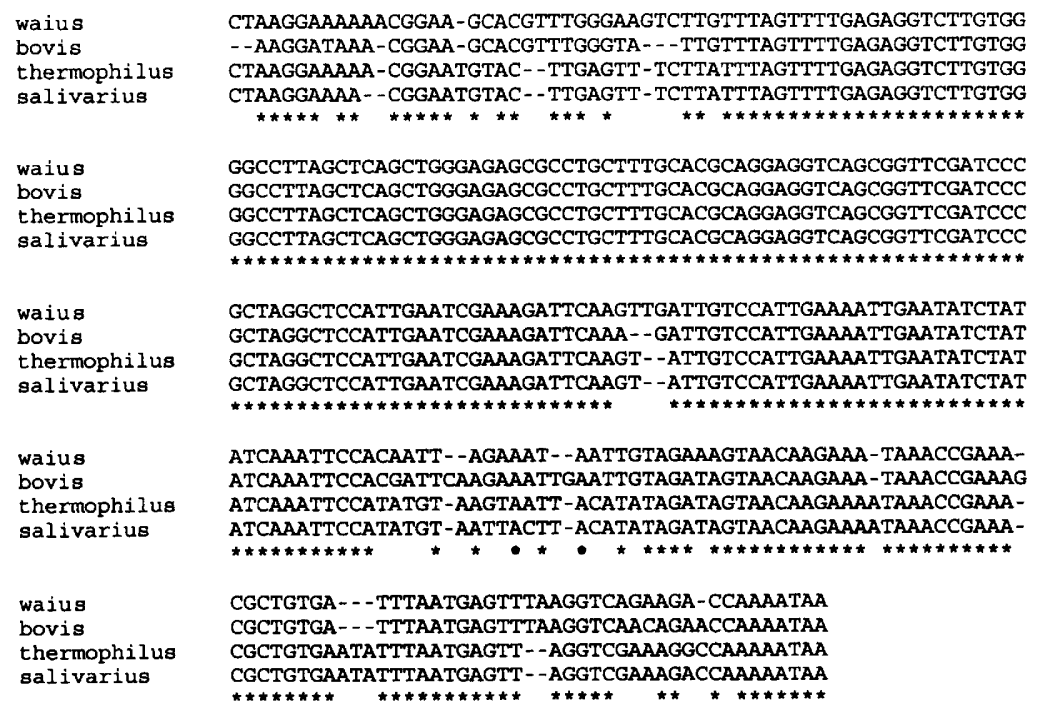

Fig. 4. Alignment of the 16S-23S rRNA intergenic spacer region of S. waius, S. bovis, S. thermophilus and S. salivarius. Asterisks indicate common bases.

Table 6. Detection of S. waius using FISH

Data shown are mean values, three replicates for each strain. Standard deviation $=0 \cdot 42$.

\begin{tabular}{|lccc|}
\hline Species & Isolate number & \multicolumn{2}{c|}{$\log _{\mathbf{1 0}}$ Cells cm $^{-2}$} \\
& & FISH probe & Acridine orange \\
\hline S. waius & $7 \mathrm{c}$ & $4 \cdot 5$ & $5 \cdot 2$ \\
S. bovis & ATCC 33317 & No detection & $4 \cdot 3$ \\
S. thermophilus & ATCC $19258^{\mathrm{T}}$ & No detection & $3 \cdot 8$ \\
\hline
\end{tabular}

\section{DISCUSSION}

The four dairy unknown isolates used in this study appeared by cell shape (Gram stain) and colony morphology to be identical to other thermophilic streptococci. All were able to grow and clot milk at $45^{\circ} \mathrm{C}$ and therefore were similar to other thermophilic streptococci (Wood \& Holzapfel, 1995). They differed from $S$. thermophilus and $S$. bovis in their range and optimum temperatures for growth, with the results for the unknown isolates lying between those for the two reference cultures. S. thermophilus, S. bovis and the unknown isolates all grew over the $\mathrm{pH}$ range $4 \cdot 0-10 \cdot 0$ and were all intolerant of bile at $1 \%$. S. thermophilus and the unknown isolates were more salt-tolerant (up to $7 \% \mathrm{NaCl}$ ) than $S$. bovis (up to $6 \% \mathrm{NaCl}$ ).

The biochemical profiles of this group of isolates were sufficiently different from those of both $S$. thermophilus and $S$. bovis, the two thermophilic streptococci associated with milk and cattle, to suggest that they may belong to another species. Enzyme profiles distinguished between the unknown isolates and $S$. bovis but profiles of the unknown isolates and $S$. thermophilus were similar.

Supportive evidence for a separate species was obtained by the differentiation of the unknown isolates from $S$. thermophilus or $S$. bovis using restriction endonuclease analysis, ribotyping and RAPD profiles. DNA-DNA hybridization confirmed the biochemical data that showed that the unknown isolates were more closely related to $S$. bovis than $S$. thermophilus. The percentage homology values between $S$. thermophilus, S. bovis and the unknown isolate $3 / 1(7 \cdot 5-32 \cdot 3 \%)$ were less than reported for the closely related thermophilic streptococci, $S$. thermophilus and $S$. salivarius (61$100 \%$ ) (Farrow et al., 1984), which therefore supports the classification of this isolate as a new species.

The $\mathrm{G}+\mathrm{C}$ ratio for this new organism is $34.6 \mathrm{~mol} \%$. The $\mathrm{G}+\mathrm{C}$ values for streptococci lie between 34 and $46 \mathrm{~mol} \%$ (Hardie, 1986). The $\mathrm{G}+\mathrm{C}$ contents of thermophilic streptococci of dairy origin, $S$. thermophilus and $S$. bovis, are 40 and $36-39 \mathrm{~mol} \%$ respectively (Hardie, 1986). The difference in $T_{\mathrm{m}}$ between $S$. waius and $S$. thermophilus was $3{ }^{\circ} \mathrm{C}$, compared with a difference of $1.6^{\circ} \mathrm{C}$ between the species $S$. thermophilus and $S$. bovis. The standard deviation for the determination of the $T_{\mathrm{m}}$ has been reported as $\pm 0.4{ }^{\circ} \mathrm{C}$ (Marmur \& Doty, 1962), and in our trials it was $\pm 0.53{ }^{\circ} \mathrm{C}$.

The inability to produce a PCR product with a primer combination specific for $S$. thermophilus or $S$. bovis rRNA genes confirmed that these organisms could not be classified as either of these bacteria. Sequence 


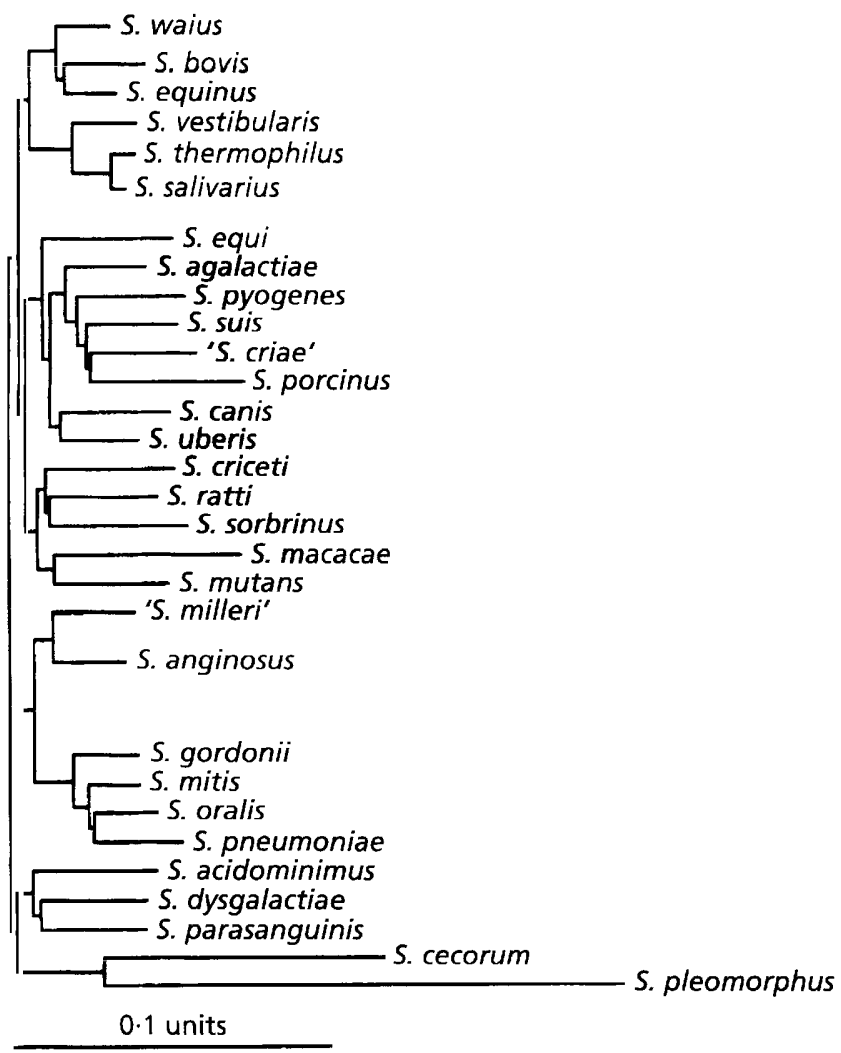

Fig. 5. Dendrogram showing the relationship between $S$. waius and 29 other streptococci.

analysis of the 16S rRNA showed that although there was the expected similarity between sequence data for these isolates and 29 other streptococci, the unknown isolates formed a separate group. Bentley et al. (1991) used comparative analysis of partial 16S rRNA sequences to categorize 24 Streptococcus species and found that $S$. thermophilus, $S$. salivarius and $S$. vestibularis formed one distinct group, and that $S$. bovis and $S$. equinus formed another distinct group. This is shown in the dendrogram constructed by aligning the $16 \mathrm{~S}$ rRNA sequences of 29 different streptococci (Fig. 5). The alignment of the 16S rRNA sequence of our unknown isolates, which we have named $S$. waius, fits between these two groups. S. waius appears to be most similar to the $S$. bovis/equinus group; however it does possess some similarity to the $S$. thermophilus/salivarius group. This is supported by the biochemical and DNA-DNA hybridization data. The intergenic $16 \mathrm{~S}-23 \mathrm{~S}$ rRNA spacer region of $S$. waius is sufficiently different from the closely related species ( $S$. bovis, $S$. thermophilus and $S$. salivarius) to provide additional support for naming this organism as a separate species.

Strains represented by $S$. bovis and $S$. equinus have been found to be very heterogeneous (Wood \& Holzapfel, 1995). Genetic and biochemical studies led to the description of two new species - Streptococcus alactolyticus and Streptococcus saccharolyticus (Wood
\& Holzapfel, 1995). Our unknown isolates do not match the phenotypic or genotypic profiles for either of these species. There are $12 \mathrm{bp}$ differences in the most variable (V2) region of the $16 \mathrm{~S}$ rRNA gene between $S$. waius and the most closely related streptococcal species (S. equinus) for which 16S rRNA data are available (Fig. 3). This compares with a 2 bp difference between the known species $S$. equinus and $S$. bovis and a $3 \mathrm{bp}$ difference between $S$. salivarius and $S$. thermophilus in the same region.

In the present study, the phenotypic and molecular data suggest that the unknown isolates should be categorized as a new species. The four dairy unknown isolates used in this study were isolated at different times from different sources and it is therefore unlikely that they belong to a clone from an identical source. This is supported by the RAPD profiles and the biochemical data where strain variations are apparent. The ability of the FISH probe to differentiate these new isolates from other thermophilic streptococci reinforces their separation into a distinct species.

\section{Description of Streptococcus waius sp. nov.}

Streptococcus waius (waius. New Zealand Maori n. waiu milk; N.L. gen. n. waius of milk).

Cells are Gram-positive, non-motile, non-spore forming, $0.7 \mu \mathrm{m}$ diameter cocci in pairs or short chains. When the organism is grown on $\mathrm{M} 17$ agar at $37^{\circ} \mathrm{C}$ for $48 \mathrm{~h}$, colonies are $0.5 \mathrm{~mm}$ in diameter, circular, convex, translucent and smooth. The organisms are homofermentative, facultatively anaerobic and catalasenegative. The organisms will clot milk at $45^{\circ} \mathrm{C}$ with an optimum temperature for growth of $38.8^{\circ} \mathrm{C}$, but are capable of growing over a range of $24 \cdot 5-52 \cdot 4{ }^{\circ} \mathrm{C}$. They will grow over the $\mathrm{pH}$ range $4 \cdot 0-10 \cdot 0$ and are tolerant of salt up to $7 \% \mathrm{NaCl}$. They are intolerant of bile at $1 \%$. The bacteria ferment galactose, D-glucose, Dfructose, D-mannose, $\mathrm{N}$-acetylglucosamine, salicin, cellobiose, maltose, lactose, melibiose, saccharose and D-raffinose. The bacterium produces the following enzymes: leucine arylamidase, valine arylamidase, cystine arylamidase, acid phosphatase, $\alpha$-galactosidase, $\beta$-galactosidase, $\alpha$-glucosidase.The DNA G+C content is $34.6 \mathrm{~mol} \%$. The habitat is milk and dairy products. The type strain is $3 / 1^{\mathrm{T}}$ and is lodged in the New Zealand Reference Culture Collection (NZRCC $20100^{\mathrm{T}}$ ) at the New Zealand Dairy Research Institute, Palmerston North, New Zealand.

\section{ACKNOWLEDGEMENTS}

We thank Marie Timmins, Colin Caddick, Tracy Coyle and Sue Rowe for excellent technical assistance, and Lesley Collins for sequence analysis.

\section{REFERENCES}

Bentley, R. W., Leigh, J. A. \& Collins, M. D. (1991). Intrageneric structure of Streptococcus based on comparative analysis of small-subunit r RNA sequences. Int J Syst Bacteriol 41, 487-494. 
Bridge, P. D. \& Sneath, P. H. A. (1983). Numerical taxonomy of Streptococcus. J Gen Microbiol 129, 565-597.

Coykendell, A. L. \& Gustafson, K. B. (1985). Deoxyribonucleic acid hybridisations among strains of Streptococcus salivarius and Streptococcus bovis. Int J Syst Bacteriol 35, 274-280.

Driessen, F. M. \& Bouman, S. (1979). Growth of thermoresistant streptococci in cheese milk pasteurizers - trials with a model pasteurizer. Zuivelzicht 71, 1062-1064.

Farrow, J. A. E. \& Collins, M. D. (1984). DNA base composition, DNA-DNA homology and long-chain fatty acid studies on Streptococcus thermophilus and Streptococcus salivarius. J Gen Microbiol 130, 357-362.

Farrow, J. A. E., Kruze, J., Phillips, B. A., Bramley, A. J. \& Collins, M. D. (1984). Taxonomic studies on Streptococcus bovis and Streptococcus equinus: description of Streptococcus alactolyticus sp. nov. and Streptococcus saccharolyticus sp. nov. Syst Appl Microbiol 5, 467-482.

Felsenstein, J. (1989). PHYLIP - phylogeny inference package (version 3.2). Cladistics 5, 164-166.

Flint, S. H., Bremer, P. J. \& Brooks, J. B. (1997). Biofilms in dairy manufacturing plant-description, current concerns and methods of control. Biofouling 11, 81-97.

Hardie, J. M. (1986). Genus Streptococcus. In Bergey's Manual of Systematic Bacteriology, p. 1069. Edited by P. H. A. Sneath, N. S. Mair, M. E. Sharpe \& J. G. Holt. Baltimore: Williams \& Wilkins.

Hardie, J. M. \& Wiley, R. A. (1994). Recent developments in streptococcal taxonomy: their relation to infections. Rev Med Microbiol 5, 151-162.

Maidak, B., Olsen, G., Larsen, N., Overbeek, R., McCaughey, M. \& Woese, C. (1997). The RDP (Ribosomal Database Project). Nucleic Acids Res 25, 109-111.
Marmur, J. (1961). A procedure for the isolation of deoxyribonucleic acid from micro-organisms. J Mol Biol 3, 208-218.

Marmur, J. \& Doty, P. (1962). Determination of the base composition of deoxyribonucleic acid from its thermal denaturation temperature. $J$ Mol Biol 5, 109-118.

Nicholas, K. B. \& Nicholas, H. B., Jr (1997). Genedoc: a tool for editing and annotating multiple sequence alignments. Distributed by the authors (www.cris.com/ $\sim$ ketchup/genedoc.shtml).

Poulsen, L. K. (1995). Protocol for the Use of Fluorescently Labelled Oligonucleotide Probes-Determination of Bacterial Identity, Activity and Gene Expression. Lyngby: Department of Microbiology, The Technical University of Denmark.

Schleifer, K. H., Ehrmann, M., Krusch, U. \& Neve, H. (1991). Revival of the species Streptococcus thermophilus (ex. OrlaJenson, 1919) nom. rev. Syst Appl Microbiol 14, 386-388.

Schleifer, K.-H., Ehrmann, M., Beimfohu, C., Brockmann, E., Ludwig, W. \& Amann, R. (1995). Application of molecular methods for the classification and identification of lactic acid bacteria. Int Dairy J 5, 1081-1094.

Southern, E. M. (1975). Detection of specific sequences among DNA fragments separated by gel electrophoresis. $J$ Mol Biol 98 , 503-517.

Thompson, J. D., Gobson, T. J., Plewniak, F., Jeanmougin, F. \& Hiffins, D. G. (1997). The CLUSTAL-X windows interface: flexible strategies for multiple sequence alignment aided by quality analysis tools. Nucleic Acids Res 25, 4876-4882.

Wood, B. J. B. \& Holzapfel, W. H. (1995). The Genera of Lactic Acid Bacteria. Glasgow: Blackie.

Young, J. P. W., Downer, H. J. \& Eardly, B. D. (1991). Phylogeny of the prototrophic Rhizobium strain BTAil by polymerase chain reaction-based sequencing of a 16S rRNA gene segment. J Bacteriol 143, 2271-2277. 